\title{
Growth and Development of Shoot on Lime (Citrus hystrix)
}

\author{
Yulian*, Yunitasari, A. Romeida, Marlin,Supanjani, and U. K. Joko
}

\author{
Department of Agronomy, Study Program of Agroecotechnology, Faculty of Agriculture, Bengkulu University \\ WR Street. Supratman, Kandang Limun, Bengkulu City, Indonesia \\ *Corresponding author: yulian@unib.ac.id
}

\begin{abstract}
Citrus hystrixis a famous horticutural crops product today. Fresh fruits of Citrus hystrix from Indonesia are mainly exported to European countries by PT Nusantara Segar Global under the trademark of Java Fresh. Futhermore, the seedlings of Citrus hystrix were also used to be a rootstock for RGL citrus due to its vigorous root growth, adataptive to marginal land, and resistance to dry season. The objective of research was to determine the effects of difference kind and concentration of cytokinin to induce shoot of Citrus hystrix. The research was conducted from January to April 2019 at the Laboratory of Biotechnology and Tissue Culture, Faculty of Agriculture, Bengkulu University. The research was designed to be Completely Randomized Block Design (CRBD). First factor was kind of cytokinin (BAP and Kinetin). Second factor was the concentration of cytokinins ( $0 \mathrm{ppm}, 1$ ppm, 2 ppm, 3 ppm, 4 ppm, and 5 ppm). Therefore, there were 12 combinations with 3 replications. The results show, the number of shoot leaf of Citrus hystrix shows a different respon to the type of cytokinin. The best type of cytokinin in the shoot of Citrus hystrix was BAP, that produced the highest number of leaves, the highest number of shoots and the heaviest wet weight of shoots, namely 10.42 leaves/bottle, 3.2 shoots and 0.46 gr. The optimum concentration of BAP was 2.58 ppm.
\end{abstract}

Keywords: Citrus hystrix, cytokinins, shoots, in vitro

\section{INTRODUCTION}

Citrus hystrixis a famous horticutural crops product today. Fresh fruits of Citrus hystrix from Indonesia are mainly exported to European countries by PT Nusantara Segar Global under the trademark of Java Fresh. Futhermore [1], the seedlings of Citrus hystrixhave a potency to be a rootstock for RGL citrus due to its vigorous root growth, adataptive to marginal land, and good resistance to dry season.

The plant was commonly cultivated in both home garden and field. Usually, citrus plants were grown well by uising liquid organic fertilizer. The liquid organic fertilizer concentration of $50 \%$ gamal leaves is capableproduces the largest number of branches [2]. Much branch the more fruits can get. The best quality of fruit product can be increases farmer income [3] In the city, the plant was usually grown in the pot as home garden. As home garden plant, Citrus hystrix gave benefits tothe families belong. For example, the plant give spiritual menu due to its beauty. The plant was also gave an oxygen therefore the air become fresh. However, when the plant was grown in the field, fruits and leaves were targeted. The plant was resistance to fruit flies. It was also save from human disturbance, due to its unedible upon mature fruits. It was known that the plant was found originally in Asia country including Indonesia. The scientific name of the plant was Citrus hystrix [4].

Low seedlings quality is a major obstacle for Citrus hystrix farmers. In addition, Citrus hystrix farmers also have limited capital, human resources, technology and information data. Tissue culture techniques are more effective when used to produce quality seedlings in a relatively short time. Tissue culture requires combination and concentration of suitable growth regulators. The growth regulators used in tissue culture also depend on the type of plant and the source of the explants [5]. The efficiency of pineapple tissue culture is largely determined by the method used. The latest and most efficient method at this time to multiply shoot of pineapple is the bioreactor technology [6].

Induction of shoots Citrus hystrix plants generally requires growth regulators, benzyl amino purine and kinetin. Cytokinins are compounds that can increase cell division in plant tissue. Cytokinins play a role in stimulating cell growth in tissue and shoot growth [7]. [8] stated that the optimum kinetin concentration for the number of tangerine shoots is 5 ppm, while for the addition of books on tangerine at a concentration of $1 \mathrm{ppm}$ Kinetin. The administration of BAP and kinetin affected the percentage of explant formation.

The research of [9] produced the best percentage of live explants of Siam Orange (Citrus nobilis Lour.), The highest percentage of shoot formation was $60 \%$ in treatment of $1.0 \mathrm{ppm} \mathrm{BAP} \mathrm{+}$ 0.5 ppm kinetin +0.5 ppm NAA. The concentration of $0.5 \mathrm{ppm}$ BAP was able to produce the highest multiplication of Chrysanthemum shoots [10]. In contrast to the research of [11] which states that the concentration of $2 \mathrm{ppm}$ BAP is able to produce the highest multiplication of shoots of mangosteen (Garcinia mangostana L.) shoots. 
The research done [12] stated that the concentration of 2 ppm benzyl amino purine without kinetin can spur the fastest shoot formation in Kuok oranges. Furthermore, the interaction of benzyl amino purine and kinetin showed the highest number of shoots and the highest shoot height, namely by treatment with a concentration of 2 ppm benzyl amino purine and 5 ppm kinetin.

The objective of the research were to determine effects of kind and cocentration of cytokinin to produce shoot of Citrus hystrix.

\section{MATERIALS AND METHODS}

This research was conducted from January to April 2019 at the Agronomy Laboratory of the Biotechnology and Plant Tissue Culture Division, Department of Agricultural Cultivation, Faculty of Agriculture, Bengkulu University. The explants used were the shoots of Citrus hystrixfrom previous research [13] which was 5 months old. The shoots used were lateral shoots with the criteria that the shoots were still fresh green.

This study has used a factorial Completely Randomized Block Design (CRBD). The first factor is the type of cytokinin which consists of 2 types, namely J1: BAP and J2: Kinetin. The second factor is the concentration of cytokinins which consists of 6 levels, namely K0: 0 ppm, K1: 1 ppm, K2: 2 ppm, K3: $3 \mathrm{ppm}, \mathrm{K} 4: 4 \mathrm{ppm}, \mathrm{K} 5: 5 \mathrm{ppm}$. Each treatment combination was repeated 3 times, so that there were 36 experimental units. Each experimental unit consisted of 1 culture bottle filled with MS media according to the treatment of $20 \mathrm{ml} /$ bottle and planted 5 Citrus hystrix shoots.
Observations were made on quantitative and qualitative variables, including number of leaves, shoot height, number of shoots, shoots appearing fresh weight, percentage of live shoots, number of shoots, and color of shoots.

Quantitative data were analyzed using the $\mathrm{F}$ test at the 5\% level. If there is a significant effect, then proceed with the Orthogonal Polynomial test. Data that does not meet the F test criteria is carried out descriptive test and displayed in the form of a histogram, qualitative data is displayed in the form of photos.

\section{RESULTS AND DISCUSSION}

In general, results of the variance analysis show a significant different. The concentrations of cytokines had a significant effect on the variable number of leaves, plant height and number of shoots and had no significant effect on shoot emergence and shoot fresh weight. Variables that have a significant effect on the $\mathrm{F}$ test at 5\% level, then further test Orthogonal Polynomials. The data were processed using the costat 6.4 software application. A summary of the results of the analysis of variance for all variables is presented in Table 1.

\subsection{The types of cytokinins on leaf number in 8 weeks after planting at 5 levels of cytokinin concentrations.}

There was a different respon the number of leaf to the type of cytokinin on 5 concentration of cytokinin at the 2 nd to 8 th week after planting. The different respon the number of leaf to the type of cytokinin is presented in Figure 1.

Table 1. Summary of analysis of variance results (ANOVA)

\begin{tabular}{|l|c|c|c|c|c|}
\hline \multicolumn{1}{|c|}{ Observation variable } & \multicolumn{5}{|c|}{ F-count 5\% } \\
\cline { 2 - 6 } & Interaction & $\begin{array}{c}\text { Types of } \\
\text { cytokinin }\end{array}$ & $\begin{array}{c}\text { Coefficient of } \\
\text { Concentration } \\
\text { of cytokinin } \\
\text { diversity before } \\
\text { transformation } \\
(\%)\end{array}$ & $\begin{array}{c}\text { Coefficient of } \\
\text { diversity after } \\
\text { transformation } \\
(\%)\end{array}$ \\
\hline Number of leaves 1 week after planting & $2.18 \mathrm{~ns}$ & $0.23 \mathrm{~ns}$ & $5.56 *$ & 108.96 & 24.82 \\
\hline Number of leaves 2 weeks after planting & $5.65 *$ & $2.36 \mathrm{~ns}$ & $6.32 *$ & 74.14 & 23.33 \\
\hline Number of leaves 3 weeks after planting & $7.53 *$ & $8.18 *$ & $6.57 *$ & 54.64 & 23.58 \\
\hline Number of leaves 4 weeks after planting & $9.33 *$ & $13.27 *$ & $8.12 *$ & 46.69 & 22.06 \\
\hline Number of leaves 5 weeks after planting & $9.05 *$ & $19.87 *$ & $7.29 *$ & 47.28 & 22.05 \\
\hline Number of leaves 6 weeks after planting & $7.66 *$ & $33.57 *$ & $8.83 *$ & 44.77 & 21.10 \\
\hline Number of leaves 7 weeks after planting & $6.40 *$ & $49.07 *$ & $8.99 *$ & 37.62 & 19.08 \\
\hline Number of leaves 8 weeks after planting & $6.20 *$ & $46.53 *$ & $9.47 *$ & 37.74 & 18.85 \\
\hline Shoot height & $2.22 \mathrm{~ns}$ & $0.08 \mathrm{~ns}$ & $1.21 \mathrm{~ns}$ & 22.54 & 13.00 \\
\hline Number of shoots & $0.99 \mathrm{~ns}$ & $20.83 *$ & $1.94 \mathrm{~ns}$ & 39.51 & 14.68 \\
\hline When shoots appear & $0.85 \mathrm{~ns}$ & $11.73 *$ & $0.67 \mathrm{~ns}$ & 33.60 & 15.40 \\
\hline Fresh shoot weight & $0.62 \mathrm{~ns}$ & $6.78 *$ & $1.59 \mathrm{~ns}$ & 52.91 & 11.11 \\
\hline
\end{tabular}

Information: * = has significant effect at the $5 \%$ level, $\mathrm{ns}=$ has no significant effect. 


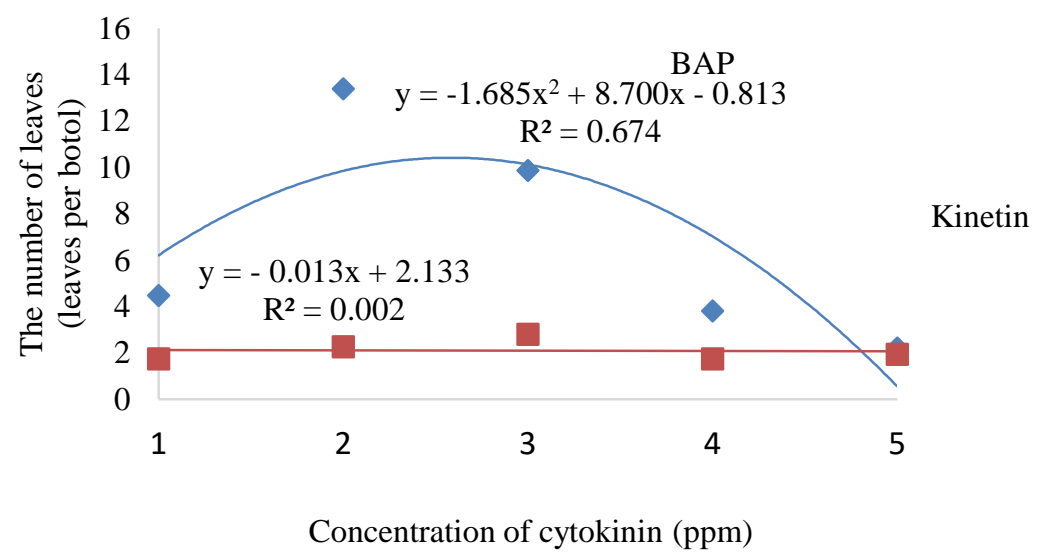

Figure 1. Respon the number of leavesto 5 levels of BAP and Kinetin concentrations.

The effect of BAP at 5 levels of cytokinin concentrations on the number of leaf resulted in a quadratic curve, with the line equation $y=-1.6857 \mathrm{x}^{2}$ $+8,7009 x-0.813$ with $R=0.6748$. Based on the quadratic equation, the optimum concentration is 2.58 ppm with the highest number of leaves, namely 10.42 leaves/bottle. While the effect of kinetin produces a positive linear regression line pattern with the line equation $\mathrm{y}=-0.0134 \mathrm{x}+2.1334$ with $\mathrm{R}=0.0022$. Based on the positive linear equation, there is the highest number of leaves, namely 2.07 leaves / bottle. The number of leaves formed in the BAP treatment reached 5 times more than the kinetin treatment up to $5 \mathrm{ppm}$. In this study, the use of kinetin was not able to respond to the formation of the leaves of Citrus hystrix shoots. The results of this study are supported by the research of [14] which states that 2 ppm BAP is able to form leaves with the highest number, namely 14 leaves on Arabica coffee shoots. In line with [15] which showed that the highest number of Phaleria macrocarpa leaves was produced in a combination of 3 ppm BAP and 0 ppm IAA, namely 57.5 leaves.

Research of [16] reported that 2 ppm BAP was the optimum concentration for shoot length and number of leaves of the mangosteen plant. But in contrast to p 5 leaves. Research in [16] showed that the concentration of $2 \mathrm{ppm}$ BAP was the optimum concentration on shoot length and number of leaves of the mangosteen plant. But in contrast to p 5 leaves. Research in [16] showed that the concentration of 2 ppm BAP was the optimum concentration on shoot length and number of leaves of the mangosteen plant. But in contrast to the research of research [17] which stated that the BAP treatment single $0.5 \mathrm{ppm}$ BAP was able to produce 2 leaves and in $1 \mathrm{ppm}$ treatment BAP had the highest number of leaves, namely 4 leaves per shoot on the Siam Orange plant.

\subsection{Multiplication response of Citrus hystrixshoots to cytokinin types}

Multiplication Response of Citrus hystrix shoots to cytokinin type spresented in Table 2.

The number of shoots formed is an important factor in shoot multiplication. The more shoots that are formed the more planting material for further propagation. The more shoots produced is an indication of the success of shoot multiplication [18]. The results showed that the number of shoots on the BAP cytokinin type, namely 3.2 shoots, was significantly different from the Kinetin cytokinin type, namely 1.7 shoots. It is suspected that BAP with 5 concentration levels was able to give the best response in spurring the formation of Purut orange shoots. The results of this study are supported by the research of [19] showed the results of the multiplication of agarwood shoots in the treatment of $0.1 \mathrm{ppm}$ NAA + 2.5 ppm BAP resulted in 12 shoots. But it is not in line with the research of [20] shows that 0 ppm NAA +2 ppm Kinetin induced the shoot of mango.

The shoots appeared 8.57 days after planting. It was significantly different to BAP, namely 13.08 days after planting. It is suspected that giving Kinetin to some extent has an effect in spurring shoot formation time according to the role of kinetin in shoot formation [21]. This research is in line with the research of [21] which showed that the appropriate treatment for the fastest appearing of musk orange shoots was by giving $5 \mathrm{ppm}$ kinetin, namely 5 days after planting.

However, it is different from the research of [12] which stated that a concentration of $2 \mathrm{ppm}$ BAP without Kinetin could spur the fastest shoot formation in Kuok oranges, namely 5 days after planting. The difference in explant responses is due to the use of different types of plants and cytokinin concentrations so that the resulting responses are also different [22].

Shoot fresh weight variable showed that BAP cytokinin type was better, namely $0.46 \mathrm{~g}$, significantly different from the kinetin which had shoot fresh weight of only 0.20 gr. It is assumed that giving BAP with 5 concentration levels is able to give the best response in cell division and shoot differentiation from the multiplication of shoot of Citrus hystrix. This study isnot in line with the research of [23] which showed the addition of $2 \mathrm{ppm}$ kinetin was able to produce the highest fresh weight of cocoa shoots, namely $0.60 \mathrm{~g}$ 
Table 2. The results of further LSD test results at 5\% level on the types of cytokinins BAP and Kinetin

\begin{tabular}{|c|c|c|c|}
\hline \multirow{2}{*}{ Types of cytokinins } & \multicolumn{3}{|c|}{ Variable observed } \\
\cline { 2 - 4 } & $\begin{array}{c}\text { Number of } \\
\text { shoots }\end{array}$ & $\begin{array}{c}\text { When shoots appear } \\
\text { (days after planting) }\end{array}$ & Shoot fresh weight \\
\hline BAP & $3.2 \mathrm{a}$ & $13.08 \mathrm{a}$ & $0.46 \mathrm{a}$ \\
\hline Kinetin & $1.7 \mathrm{~b}$ & $8.57 \mathrm{~b}$ & $0.27 \mathrm{~b}$ \\
\hline
\end{tabular}

Note: Figures in the same column followed by the same letter do not differ based on the LSD test at 5\% level.

\subsection{Descriptive Analysis}

Table 3. Average value of shoot height, color of shoots and percentage of lifeexplants

\begin{tabular}{|c|c|c|c|c|}
\hline \multicolumn{2}{|c|}{ Treatment } & \multirow[b]{2}{*}{ Shoot height $(\mathrm{cm})$} & \multirow[b]{2}{*}{$\begin{array}{l}\text { Percentage of } \\
\text { shoots life }(\%)\end{array}$} & \multirow[b]{2}{*}{ Color of shoots } \\
\hline $\begin{array}{l}\text { Types of } \\
\text { cytokinins }\end{array}$ & $\begin{array}{c}\text { Concentrations of } \\
\text { cytokinins }\end{array}$ & & & \\
\hline BAP & $1 \mathrm{ppm}$ & 0.82 & 93.33 & 5 GY $7 / 10$ \\
\hline BAP & $2 \mathrm{ppm}$ & 1.27 & 93.33 & $5 \mathrm{GY} 7 / 6$ \\
\hline BAP & $3 \mathrm{ppm}$ & 1.11 & 93.33 & $2.5 \mathrm{GY} 8 / 6$ \\
\hline BAP & $4 \mathrm{ppm}$ & 0.80 & 100.00 & $2.5 \mathrm{GY} 8 / 6$ \\
\hline BAP & $5 \mathrm{ppm}$ & 0.58 & 93.33 & $5 \mathrm{GY} 5 / 8$ \\
\hline Kinetin & $1 \mathrm{ppm}$ & 0.80 & 100.00 & 5 GY 5/8 \\
\hline Kinetin & $2 \mathrm{ppm}$ & 0.74 & 93.33 & $2.5 \mathrm{GY} 5 / 8$ \\
\hline Kinetin & $3 \mathrm{ppm}$ & 0.85 & 100.00 & 5 GY 6/6 \\
\hline Kinetin & $4 \mathrm{ppm}$ & 0.68 & 80.00 & $5 \mathrm{GY} \mathrm{5/10}$ \\
\hline Kinetin & $5 \mathrm{ppm}$ & 0.85 & 86.67 & $5 \mathrm{GY} 5 / 8$ \\
\hline
\end{tabular}

Description: GY = Green Yellow

\subsubsection{Shoot height}

Table 3 shows that the addition of 5 levels of cytokinin concentrations resulted in shoot heights ranging from $0.58 \mathrm{~cm}-1.27 \mathrm{~cm}$. It is suspected that the addition of cytokinin concentrations has not been able to give the best response to shoot growth. The results of this study are not in line with the research of [24] which showed that the average height of explants in the $0 \mathrm{ppm}$ BAP treatment resulted in the highest average shoot height of $5.41 \mathrm{~cm}$ in the multiplication of cotton shoots.

Research [25] stated that the best shoot height in Samama shoot multiplication showed that the highest average shoot height was produced by 1 ppm BAP treatment, namely $1.2 \mathrm{~cm}$. Research by [19] also showed that the treatment of $3 \mathrm{ppm}$ kinetin was able to have an effect on the shoot height of Kasturi lime, which was $7.1 \mathrm{~cm}$. Research by [26] also showed that the best Jatropha shoot extension was DKW +5 ppm Kinetin.

\subsubsection{Percentage of live shoots}

The results showed the percentage of live shoots ranged from $80 \%-100 \%$. The highest percentage of shoot life, namely $100 \%$, resulted from treatment of $4 \mathrm{ppm}$ BAP, $1 \mathrm{ppm}$ Kinetin and $3 \mathrm{ppm}$ Kinetin see (Table 3). The results of this study are in line with the research of [21] that the treatment of 5 ppm kinetin +2 ppm NAA and 3 ppm Kinetin $+1 \mathrm{ppm}$ NAA showed that the percentage of explant growth reached $100 \%$. This is because the provision of auxins and cytokines exogenously or endogenously is capable of being a trigger in tissue growth and development.
However, the results of this study are not in line with the research of [17] which states that the provision of a single 0.5 ppm- 1 ppm

BAP shows the percentage of shoot formation of $100 \%$. However, there was a decrease in the percentage of shoot formation at $2 \mathrm{ppm}$ BAP.

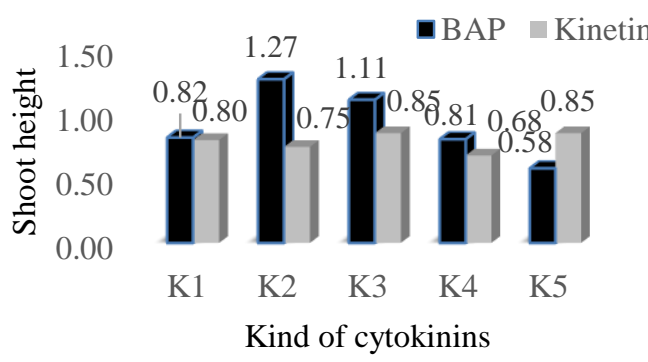

Picture 2. Histogram average shoot height at 8 weeks after planting.Note: $\mathrm{K} 1=1 \mathrm{ppm}, \mathrm{K} 2$ $=2 \mathrm{ppm}, \mathrm{K} 3=3 \mathrm{ppm}, \mathrm{K} 4=4 \mathrm{ppm}$, and $\mathrm{K} 5$ $=5 \mathrm{ppm}$

\subsubsection{Color of shoots}

The colors of all plantlets in this study are generally yellowish green. There was no tendency that the addition of cytokinin concentrations would increase the green color of the Purut orange shoots. This is thought to be due to the presence of endogenous auxins which inhibit the action of cytokines in encouraging the formation of chlorophyll [27]. 
This study is in line with the research of [28] which states that the chlorophyll content (both chlorophyll-a, chlorophyll-b and total chlorophyll) in in vitro plants is lower than plants in the field. In this study, the best shoot color was shown in the treatment of $5 \mathrm{ppm}$ BAP, $1 \mathrm{ppm}$ kinetin and $5 \mathrm{ppm}$ kinetin, namely 5 GY $5 / 8$ which showed a lighter green color than other treatments.

Table 4. The development of shoot color of Citrus hystrixat 8 weeks after planting

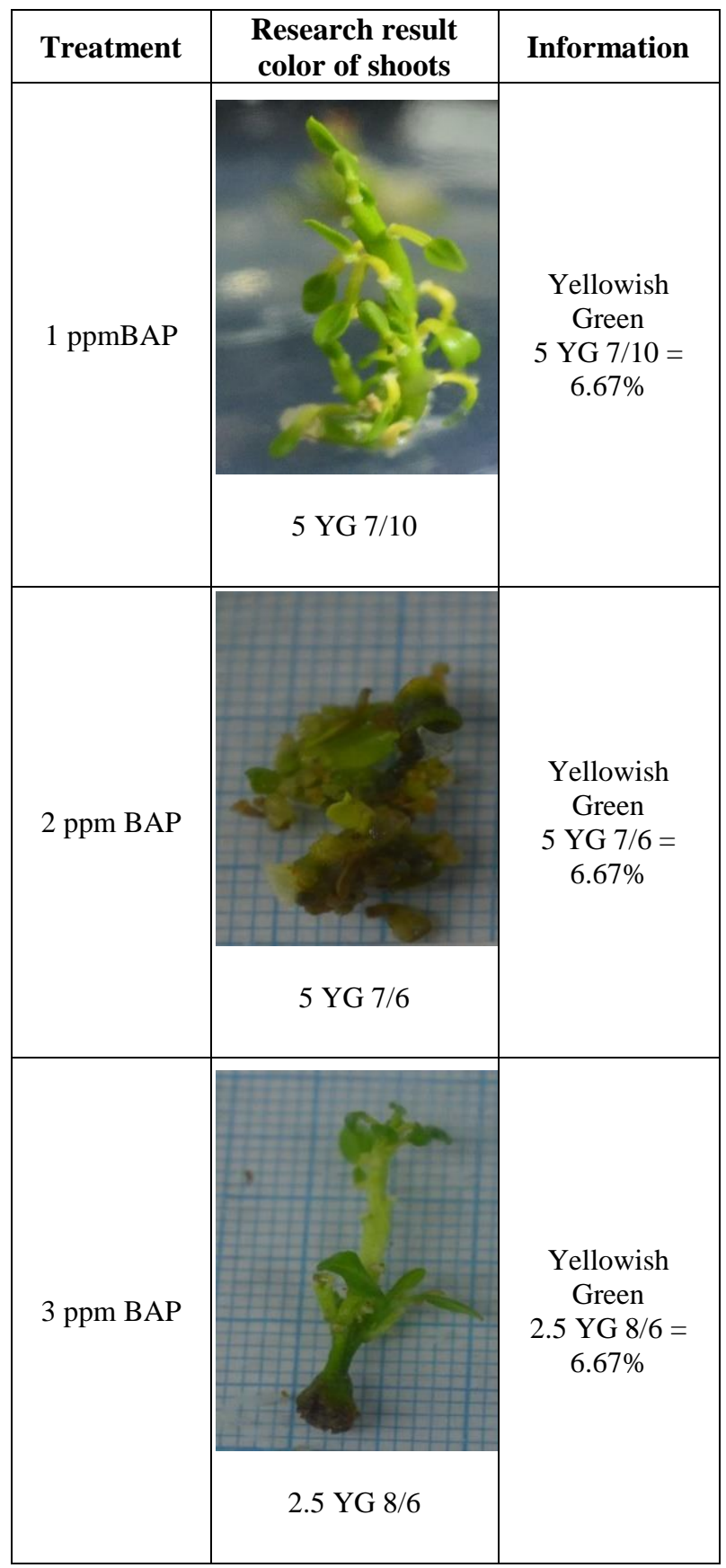

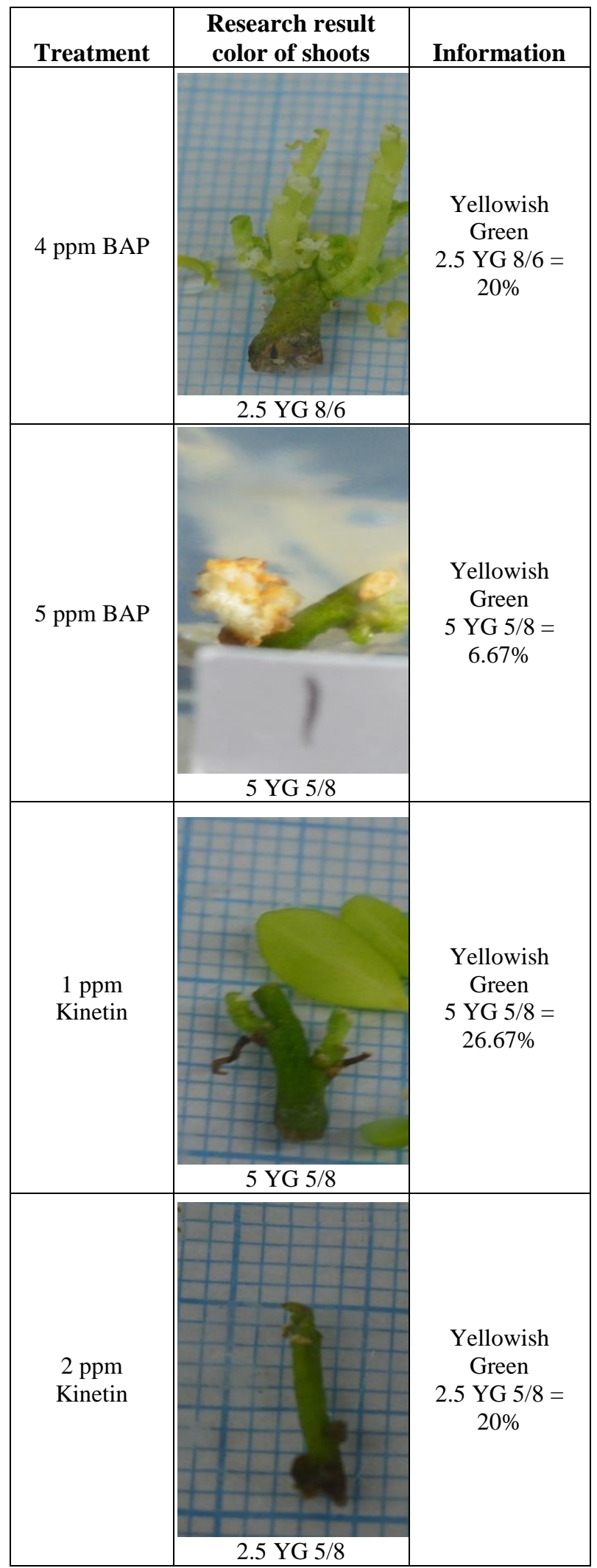




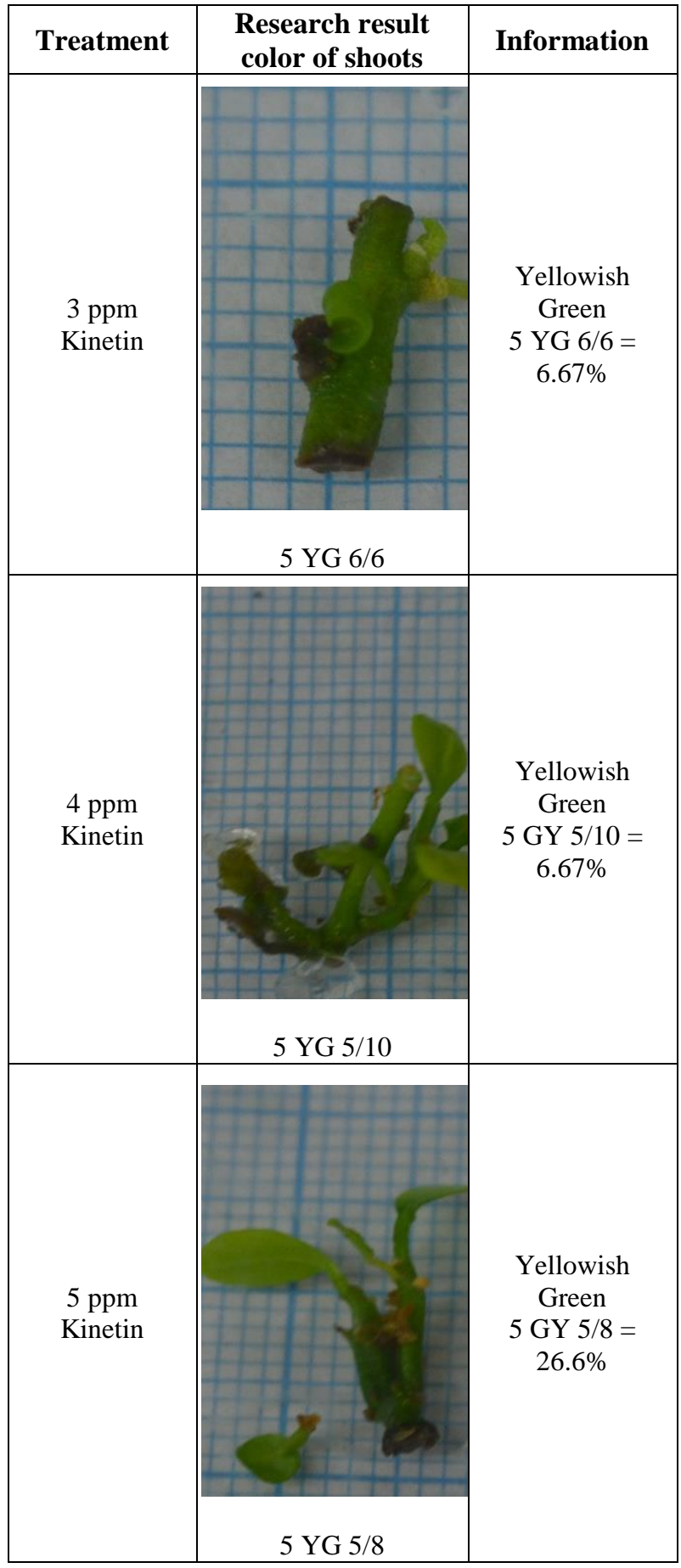

\section{CONCLUSION}

1. The number of leaf of Citrus hystrixshows adiferencerespon to the type of cytokinin.

2. The best type of cytokinin in the shoot multiplication of Citrus hystrix was BAP, that produced the highest number of leaves, the highest number of shoots and the heaviest wet weight of shoots, namely 10.42 leaves/bottle, 3.2 shoots and 0.46 gr. Whereas the fastest shoots appeared in the control treatment (without BAP and Kinetin) which resulted in the fastest shoots appearing at 7.26 day after transplanting.
3. The optimum concentration of BAP was 2.58 ppm,resulted in the highest number of Citrus hystrixleaves, namely 10.42 leaves/bottle

\section{ACKNOWLEDGMENT}

The author acknowledges the research fund for Applied Research 2018 Fiscal Year received from The Ministry of Research, Technology and Higher Education Indonesia for conducting this research.

\section{REFERENCES}

[1] J. Asmi, Yulian, and Widodo. "Growth ofsevenlocal types of Lime (Citrus sp.) on $\mathrm{pH}$ different media of hydroponic open system". Program and Abstract Book of ICOSAT International Seminar UPM Malaysia, 2018 .

[2] L.R. Utami, Yulian, B. Sulistyo. "Pertumbuhan vegetative bibit jeruk gerga pasca okulasi pada konsenterasi pupuk organic cair yang berbeda". Jurnal-jurnal Ilmu Pertanian Indonesia, vol. 21, no. 1, pp. 32-36, 2019.

[3] Yulian, Prasetyo, Widodo, Fahrurrozi and W. Thevaldo. "Grading buah jeruk keprok gerga(Citrus Sp.) meningkatkan penerimaan usahatani". Prosiding Seminar Nasional PengentasanKemiskinan, RENPER. Bengkulu, pp: 39-46, 2019

[4] A. Agusta.Minyakat siri tumbuhan tropika Indonesia. "LaboratoriumFitokimiaPuslitbangLIPI”. InstitutTeknologi Bandung, Bandung, 2000.

[5] E.G. Lestari. "Peranan zat pengatur tumbuh dalam perbanyakan tanaman melalui kultur jaringan. Balai Besar Penelitian dan Pengembangan Bioteknologi dan Sumberdaya Genetik Pertanian”. JurnalAgroBiogen, vol. 7, no. 1, pp. 63-68, 2011.

[6] L. Valentina, Yulian, O. Sittichan and S. Sripaoraya. "Shoot multiplication of HQC34 hybrid pineapple (Ananas comosus L.) via bioreactor with different concentrations of 6benzylaminopurineand MS media. Program and Abstract Book of The First International Symposium on Botanical Garden and Landscapes". Bangkok, Thailand, 2019.

[7] F.R. Lina, E. Ratnasari dan R. Wahyono, "Pengaruh 6-benzylamino purinedan 6-furfuryl amino purine pada media MS terhadap pertumbuhan eksplan ujung apical tanaman Jati secara in vitro". LenteraBio,vol. 2, no. 1, pp. 5761, 2013. 
[8] I. Putra, M. Arisudana., A. Purwito dan M. Kosmiatin. "Propagasi mikro dan sambung mikro Jeruk keprok (Citrus reticulata)Garut hasil mutagenesis in vitro dengan batang bawah Japansche citroen". J. Hort. Indonesia, vol. 6, no. 2. pp. 99-108, 2015.

[9] S. Cahyat., M. N. Isda dan W. Lestari. "Induksi tunas dari eksplan kotiledon dan epikotil in vitro Jeruk siam (Citrus nobilis lour.) asal Kampar pada media MS". Jurnal Riau Biologia, vol. 1, no. 5 , pp. 31-38, 2016.

[10] B.S. Indriani. "Efektivitas substitusi sitokinin dengan air kelapa pada medium multiplikasi tunas Krisan (Chrysanthemum indicum 1.) secara in vitro". Skripsi MIFA Universitas Negeri Semarang. Semarang, 2014.

[11] E. Nursetiadi. "Kajian macam media dan konsentrasi BAP terhadap multiplikasi tanaman Manggis (Garcinia mangostana L.)secara in vitro". Skripsi. Universitas Sebelas Maret. Surakarta, 2008.

[12] W. Safitri, I. "Mahadi dan Darmawati. Multiplikasi tunas dengan metode kultur jaringan Jeruk kuok (Citrus Nobilis Lour)menggunakan hormon benzyl amino purine dan kinetin sebagai rancangan lembar kerja siswa biologi di SMA". Universitas Riau, Riau, 2016.

[13] Y. Fatmawati, "Pengaruh konsenterasi NAA dan BAP terhadap multiplikasi eksplan jeruk purut (Citrus hyxtrix) secara in vitro". Skripsi Fakultas Pertanian UNIB, 2019.

[14] M.S.D.Ibrahim, dan RR. S. Hartati. "Multiplikasi tunas kopi arabika menggunakan kinetin dan 6benzylaminopurine. Prosiding Seminar Nasional Agroinovasi Spesifik Lokasi untuk Ketahanan Pangan pada Era Masyarakat Ekonomi ASEAN". Balai Penelitian Tanaman Industri dan Penyegar. Bogor, 2015.

[15] Nirwan dan S. A. Aziz. "Multiplikasi dan pigmentasi antosianin daun Dewa(Gynura pseudochina (L) DC) in vitro". Bul. Agron, vol. 34, no. 2, pp. 112-118, 2006.

[16] E. Nursetiadi. "Kajian macam media dan konsentrasi BAP terhadap multiplikasi tanaman Manggis(Garcinia mangostana L.) secara in vitro".Skripsi. Universitas Sebelas Maret. Surakarta, 2008.

[17] S. Rohmawati, S. Fatonah dan M. N. Isda. "Multiplikasi tunas in vitro dari eksplan nodus Jeruk siam(Citrus nobilis LOUR.) asal Kampar dengan penambahan benzylamino purine dan ekstrak malt". Repository Universitas Riau. Riau, 2015.

[18] S. Aini, N. "Multiplikasi tunas Jeruk keprok Tawangmangu(Citrus nobilis L.)dengan variasi konsentrasi IBA dan kinetin". Skripsi. Fakultas
Pertanian Universitas Sebelas Maret. Surakarta, 2012.

[19] R. Julianti, S. Wulandari dan H. Darwati. "penambahan NAA dan BAP terhadap multiplikasi subkultur tunas Gaharu(Aquilaria malaccensis Lamk)". Fakultas Kehutanan. Universitas Tanjung Pontianak. Pontianak, 2013.

[20] H. Alif, I. Suliansyah dan Gustian. "Inisiasi dan multiplikasi mangga Tarusan(Mangifera indica 1.)secara in vitro". Prosiding Semirata BKS PTN Wilayah Barat Bidang Ilmu Pertanian. Universitas Sultan Ageng Tirtayasa Serang Banten, 2009.

[21] I. Mahadi, W. Syafi'i dan S. Agustiani. "Kultur jaringan Jeruk kasturi(Citrus Microcarpa)dengan menggunakan hormon kinetin dan naftalen acetyl acid (NAA)". Jurnal Dinamika Pertanian, no. 30, pp. 37-44, 2015

[22] N. Hidayat, W. Lestari dan M. N. Isda. "Induksi Tunas In Vitro Jeruk Siam(Citrus nobilis Lour.)asal Kampar dari eksplan tunas apeks dan nodus in vitro". JOM FMIPA, vol. 1, no. 2, pp. 275- 282, 2014.

[23] S. Rizal, W. E. Murdiono dan E. Nihayati. "Pengaruh pemberian beberapa konsentrasi kinetin terhadap induksi tunas aksilar tanaman Kakao(Theobroma cacao. L) secara in vitro". Jurnal Produksi Tanaman, vol. 5, no. 9, pp. 1512-1517, 2017.

[24] L. Mastuti, R.P. Sari., dan S.L. Asmono. "Multiplikasi tunas tanaman Kapas (Gossytium spp.)varietas Kanesia 15 menggunakan kombinasi BAP dan NAA secara". in vitro. Agriprima, Journal of Applied Agricultural Sciences, vol. 2, no. 2, pp. 171-181, 2018.

[25] L.L. Djumat. "Multiplikasi in vitro Samama (Antho cephalus macrophyllus (ROBX). Havil)melalui tunas pucuk dan tunas aksilar". Program Studi Kehutanan Fakultas Pertanian UNIDAR Ambon. Bimafika, 2014.

[26] T. Lizawati. Novita dan R. Purnamaningsih. "Induksi dan multiplikasi tunas jarak pagar (Jatropha curcas L.)secara in vitro". J. Agron. Indonesia, vol. 37, no. 1, pp. $78-85,2009$.

[27] H. Fitriani. "Kajian konsentrasi BAP dan NAA terhadap multiplikasi tanamanArtemisia annua L.secara in vitro". Skripsi. Fakultas Pertanian. Universitas Sebelas Maret. Surakarta, 2008.

[28] Hafiizh. E. A., D. R. Wulandari dan T. M. "Ermayanti.Seleksi media dan perbanyakan tunas Taraxacum officinale Weber ex f.h. Wigg melalui regenerasi spontan secara in vitro untuk penyediaan bibit berkualitas". Berk. Penel. Hayati, no. 4A, pp. 91-98, 2010. 